\section{合成高分子材料への期待 医学的利用面からの展望}

生体材料(Biomaterials)k要求 される条件としては，まず生化学 的適合性 (Biochemical compatibility) があげられる。ポリマー 分子を破断するよらな化学反応は しばしば主鎖の末端から始まる。 平均分子量が高ければ高い汪ど， 反応性末端基す少なくなるので生 体内でより安定である. 高分子化 学はいろいろな高分子に和ける結 合の安定性について既に多くの知 識をもっている。これに基づいて ポリマーの生体内安定性について 一つの推論を導き出すことは, ポ リマーの生体内安定性を考えるら えで妥当な出発点となるである う.しかし, 生体内環境に沏いて 㹥しばしば特殊な反応が若起さ れ，一概に論じきれないものがあ る。一般汾分子内に親水基の多い ポリマーほど生体内での反応性は 高く，柾水性になる㴗ど低い，例 えば,ナイロンやセルロースのよ らに分子構造が生体高分子（タン パク，多糖類など）に近い注ど生 体内で膨潤, 解膠されやすく, 周 因組織を刺激したりアレルギー反 応を引き起こてたりする，これに 反して, 生体高分子とは全く異な ったシリコーンゴム, ポリェチレ ソ，ポリテトラフルオロエチレン などは安定性が高い。

つぎに組織接着性 (Bioadhesiveness）について述べてみよう. 生体内で安定性の高い蹯水性ポリ マーの多くは周囲組織との接着性 は一般に悪い。したがって，グラ フティングや微細多孔によって
柾水性ポリマーの表面性状を改良 するこころみはバイオメディカル ポリマーの重要な課題となってい る. 組織・ポリマー界面をどのよ らに結合させるか，また，させな いか性重要なことがらで, 生体内 に埋入されたポリマーの表面には 体液や血液成分の吸着が起こり, 材料 - 細胞間にはいろいろな生体 由来の高分子が吸着し介在する. これらの相互関係が一連の分子構 造モデルとして説明されるとき， はじめて適性材料開発のプログラ ムが確立される。これには分子生 物学や界面科学分野の専門知識が とくに要求される，合成高分子之 生体高分子との反応形式を分子レ ベルで説明しようとする作業は血 栓形成や免疫反応，発がんなどの 機棈解明にも役立つものであり， 生命の本質に切りこむ手段でもめ 万。

最後飞生物力学的安全性 (Biomechanical compatibility) kつ いてられてみたい，生体内での安 定性が高く組織接着珄の大きい材 料としては金属やセラミックスが あげられる。しかしこれらの材 料の多くは弾性係数が歯や骨より もはるかに大きい，これに反して ポリマー（複合材料を含む）では 期待する物性が自由に得られる。 生体材料の物性が修復される局所 組織の粘弾性的性質に合致しなけ れば，生体組織のひずみに材料が ついていけない。

それゆ方, 材料-組織界面では応 力集中により, 分離や裂断, 破壊
が発生し，周囲組織に対して機的 的刺激をあた光慢性炎症を誘発 し，発がんの挌それもある。どの ような素材で, ぞのような構造体 をつくり, 複雑なフィードバック システムをもった生体系のなか で，どのようと調和させ，正常な 機能を営ませるかといらことは重 大な課題である.

肉眼的構造から分子構造までを 含めて概観するとき，そこには生 命の本質をとら兄る手段として分 子生物学が歩んだ道とは別途の生 体力学的(機構学)アプローチの存 在が認識される。もちろん, 標的 は一つであるから，これらのアプ ローチ㥽点では一つになるはず である。

（大阪歯科大学理工学教室 - 教授, 専門=バイオマテリアルズ, 組織 培養） 
医用高分子材料の開発 鶴田禎二

\section{分子設計の立場から}

最近, 医用高分子材料の研究開 発に当たって，多相系材料表面の もつ優れた生体適合性が各方面で 注目され，現在では，医用材料の 分子設計を行なう際の有力な仕事 原理の一つになっている.

1972 年 10 月, 今井庸二, 增原 英一らは日本人工臟器学会におい て, ミクロ不均質表層構造が示す 優れた抗㠜血性について報告し， 両者の相関性を、はじめて明確な 形で指摘した. 1972 年 11 月号の “高分子”には今井の詳細な解説 が揭載されている.彼らの観察し たミクロ相はだいたい1〜数ミク ロン程度の䉇囲に岁った、今井ら は Avcothane や Biomer など のブロック共重合体のるつ優れた 抗凝血性もミク口相分離に基づく

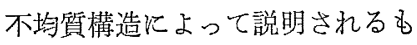
のと推測した。

D. J. Lyman は TASAIO(1972) K, セグメントポリェーテルウレ タンウレア (PEUU) と, 腎細胞 や血小板との相互作用の様相が, PEUU 飞特けるポリエーテル部 分の分子量の大小によって顕著な 影響を受けることを報告した。彼 はここで細胞や血小板の粘着挙動 飞影響するのは材料表面の “microarchitectural effects”である うと述べている. 1975年, Lyman

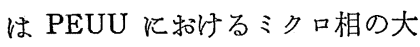
きさを30〜100 § と推測した。 一方, 1967 年ごろから, ブロッ ク グラフト共重合体のミクロ相 分離構造を電子顕微鏡によって直 接観察することが 可能となった
が, これらの場合，ミクロドメイ ンの大きさは $1,000 \AA$ 前後のもの が多かった。ヒドロキシェチルメ タクリレート (HEMA) にポリス チレンマクロマーやPMMA マク ロマーを共重合させてつくった自 己補強性ヒドロゲル（クラレ, 1972 年, 1975 年) も $200 \sim 300 \AA$ 付近のドメインをもち，優れた血 液適合性を示すことが明らかにさ れた。

1976年, 岡野光夫, 篠原 功ら が分子設計した HEMA，スチレン のA-B-A型ブロック共重合体は， $\mathrm{A} / \mathrm{B}$ 比に応じてミクロ相の模様 が顕著に変化する，膜表面にラメ ラ模様を形成させるよう調整した ときに, この共重合体の血液適合 性は最良のものとなった。この場

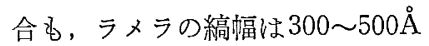
であった(岡野ら括よび赤池敏宏， 桜井靖久ら，1978 年).筆者の研究 グループで, 1978年合成したポリ アミンくし型グラフト共重合体で は, ドメインの大ささを 0.1 数 ミクロンになるよう設計すると， 得られた膜面は, 血小板をよく粘 着し, しかも粘着した血小板に形 態変化をほと儿ど起こさせなかっ た. 桜井, 片岡一則らはこの種の 問題を発展させ, 細胞膜の “capping control” に結びつける可能 性を検討している.

現在, 最良の生医学材料といわ れる Avcothane, Biomer 岁る いは PEUU のミクロ相の大きさ そついての明確な情報は最近まで ほとんど得られてはいなかった。
1980年, 高柳素夫，梶山千里らは Biomer 型のポリウレタンの小角 X線散乱像を解析し, hard および soft segment のドメインの大き

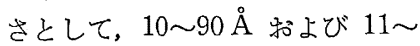
$20 \AA ̊$ の值をそれぞれ報告した。 た, Avcothane や Biomer, とく 飞前者では膜面に垂直な方向にむ 不均質性の著しいことが ATR IR, ESCA, Auger などの測定 (C.S.P. Sung $5,1978,1979) k$ よって次第に明らかにされつつあ る.

上汇述べた諸例の活か，特異な 生医学的挙動宗す多相系材料が 多数各方面で見いだされつつあ る.しかし，なぜ多相系材料がそ らなのかといら疑問付対しては, 残念ながら，涪とんど解答がなさ れてはいない，事情が非常腹襍 で錯綜しているからである。多相 系材料飞乱路只口相の種類や 形態と生医学的挙動との相関関係 を追究する地道な努力が今後な和 いっそう必要となるであるう。皇 して, この努力こそが, 次代に和 ける新しい生医学材料の分子設計 への大きい駆動力になるるのと私 は信じている.

（東京理科大学工学部 - 教授, 專 門=高分子合成）

\section{れご意見・ご感想をお寄せ下さい}

この提言を和読みになった，み なさまのご意見, ご感想を打寄せ 下ざい.

字数 $=1,000$ 字程度

締切 $=7$ 月 30 日

送付先＝会誌「高分子」編集委 員会 